\title{
Bowel Perforation Indicator
}

National Cancer Institute

\section{Source}

National Cancer Institute. Bowel Perforation Indicator. NCI Thesaurus. Code C156504.

An indication as to whether bowel perforation has occurred. 